\title{
Between trust and hope: the Justice and Development Party and the Alevis in Turkey
}

\begin{abstract}
This article reviews the position of the Alevis in Turkey, a group of Turkish Muslims with a different set of beliefs to the Sunnis which make up the majority of Turks, and with particular regard to the stance of the JDP, the ruling party, vis-à-vis the secularism on which the Turkish state was founded. In drawing attention to the nature of the beliefs of Alevis, and the myths and misunderstandings which surround them, as well as the pogroms and massacres that have occurred within living memory, and which have combined to exclude them from mainstream society regardless of the party in government, the author highlights the fears of the community arising from the JDP being seen as the representative of Sunni Islam. This is particularly the case given the JDP's own origins within the National Vision discourse and the policy stances which it has adopted while in government. The relationship might be dominated by mutual distrust, but the JDP, in remaining insensitive to the problems of Alevis, is endangering the persuasiveness of other democratisation efforts.
\end{abstract}

Keywords: secularism, National Vision, identity, freedom of belief, discrimination, assimilation, majoritarianism

\section{Introduction}

The sectarian policies that the Ottoman Empire exercised among its Muslim citizens, ever since the $15^{\text {th }}$ century, have been known to affect the development of the Turkish Republic which has inherited some of its policies, in one way or another. Seen as the focus of political and religious deviance by the Ottoman administration, which is based on Hanafi-Sunni Islam, the isolation of Alevis from executive positions and from other positions of power that the government has provided has resulted in the continuance of their marginal situation in practice, if not in the constitutional sense following the establishment of the Turkish Republic.

The Republic's constituent cadres, coming from Sunni Islam circles, decided on a Sunni interpretation of Islam, a choice which was possibly the result of a cautious policy of unification based on the belief of the majority and in the case of having to confront various problems during the establishment of a young state rising from the debris of the Ottoman Empire. The Republican People's Party, the founder of the Republic, comprehended a Turkish version of 'secularism' which, together with this perception of Sunni Islam, has shaped the religious area. From a political or a religious perspective, it is easily noticeable that all right- and left-wing parties in Turkey have helped to form a religious space which is in accordance with Sunni Islam. 
Within this framework, the Justice and Development Party (Adalet ve Kalkınma Partisi, or AK PARTİ, in Turkish), which addresses a more religious part of society, has built its political identity on Hanafi-Sunni Islam. This identity is reflected in the policies that the JDP government between 2002 and 2014 has followed. One of the most important examples that are manifested in such a reflection is the JDP's approach to the issue of Alevism.

In this article, the JDP's approach to Alevis will be discussed in four sections examining how and at which level such policies are reflections of its background. At the same time, some general background on Alevism will be provided, alongside an examination of the JDP's and Alevis' conceptions of each other. Subsequently, we discuss some particular events in order to understand the JDP's Hanafi-Sunni identity vis-àvis Alevism. The path being followed is, in this respect, an attempt to explain the issue by demonstrating the attitude of the JDP in the face of the problems experienced by Alevis. Such problems are listed as the manner of the JDP related to problems concerning obligatory Religious Culture and Ethics (RCE) courses; the attitude of the JDP in the case of problems related to cemevi ${ }^{1}$ and the JDP's approach to issues related to the Directorate of Religious Affairs (the Diyanet). Finally, we discuss the perspective for success of particular JDP activities, known as the Alevi initiative.

When these issues are evaluated, it will be clear that the JDP has not built a carefully considered, healthy relationship with Alevis as a result of its Hanafi-Sunni orientation. The JDP's leader, Recep Tayyip Erdoğan, has, as many politicians do in times of crisis, tried to ignore problems and to avoid crises, by making statements such as 'If being an Alevi means loving Ali, then we are Alevis, too' ${ }^{2}$ instead of finding a solution to the matter. According to such an approach, an Alevi is who they define it to be and, from that point of view, they are also Alevis; in contrast, where those who call themselves Alevis do not fit the definition provided by the JDP, they are not regarded as Alevis. In both cases, there is no such problem for JDP politicians as Alevism. According to this opinion, the problems of Alevis have been artificially created by those outside this community: such people are 'atheists' and/or 'communists.'

The JDP's perception of Alevism is, therefore, an artificial one which does not take history into account. Starting from the Hanafi-Sunni identity, and going back as far as defining Alevis in spite of them, building their relations with Alevis based on such a definition, the JDP's mistaken perception prevents the Party from diagnosing the problems of Alevis and, thus, it does not address their issues.

In many ways, the course of the relationship between Alevis and the JDP functions as a laboratory for seeing the differences between theory and practice. The JDP's party programme functions as litmus paper in showing the difference between the JDP's national and international image, as well as its practices and level of democratic understanding. That is: on the one hand, a political party which claims to stand for freedom of belief, which is steering a course towards Europe and denying its roots and National

1 Alevi places of worship.

2 Erdoğan's statement is as follows, 'If Alevism is to love Ali and to live one's life like he did, I'm a person who has tried to live like he did, all my life. Then, I am much more of an Alevi than they.' 'Erdoğan: İlerleme raporunda ayrımcılık yapıldı' Hürriyet 7 October 2004. 
Vision - as Erdoğan says, 'We have taken off our National Vision shirt'; ${ }^{3}$ on the other hand, there exists a community - the Alevis - who have been exposed to discrimination for their beliefs both before and during the JDP government.

It would be appropriate to add that there has been distrust and a lack of sufficient dialogue between both sides in this historical process, although it is successive governments that have caused and instigated this discrimination by being a part of it: Alevism has been a problematic issue not only for the JDP but also for all political groups that have been in power. Looking at the history of the Republic in general, the attitudes of both civil and military bureaucracies have been similar in terms of ignoring Alevis on issues related to religious education and services. ${ }^{4}$ Before and during the JDP government, both civil and military administrations have construed Islam in accordance with the Hanafi interpretation of Sunni Islam. The other interpretations of Islam, especially Alevism, have been ignored over a period of time and they have also been excluded using the power of the state. In recent times, it may clearly be observed that a momentary set of policies has been preferred in order to resolve particular problems when it has not been possible to implement such a strategy.

The relationship between Alevis and the JDP continues to be of high-level importance in displaying the positions of Alevis, the second largest religious community, during this second period of one-party government and this is an indicator of whether or not the JDP's expression of democracy is reflected in reality.

A group of people within the leading cadre of the JDP is also known to be a member of the political movement called Milli Görüş (National Vision) which also encompasses former members of the Motherland Party and the True Path Party (TPP). National Vision has been encompassed by political parties such as the National Order Party, established by Necmettin Erbakan; the National Salvation Party (NSP); the Welfare Party (WP); and the Virtue Party (VP). After the VP was declared unconstitutional by the Constitutional Court, and then banned in June 2001, because it was seen as the successor of the WP, its parliamentary deputies divided into two different active political parties, the Felicity Party (FP) and the JDP, in order that the deputies could continue to take part in politics.

The JDP was the first party to win three general elections in Turkey in succession, while it also won elections in the interim: the 2002 general election; the 2004 local elections; the 2007 general election; the 2009 local elections; and the 2011 general election. The JDP chooses to follow a different path from that of National Vision in questions of the economy, foreign policy and relations with European Union, but it has been faithful to the sensitivity of core National Vision voters concerning issues of religion and secularism. It is also evident that the JDP is dealing with the issues of the

3 'AKP'nin yeni zarfi' Radikal 26 December 2003; 'Milli Görüş gömleğini çıkardı, herkesi kucakladi' Sabah 3 August 2007.

4 For the effects of the Ottoman legacy, based on Sunni Islam, on the institutions of state, see Markus Dressler (2008) 'Religio-Secular Metamorphoses: The Re-Making of Turkish Alevism' Journal of the American Academy of Religion 76(2), June: 282-284. 
turban/headscarf in universities, the existence of İmam-Hatip high schools and problems related to bureaucratic cadres in line with this sensitivity. ${ }^{5}$

In addition to the JDP's populist policies related to these particular issues, the economic stability gained through the economic policies which have been implemented and the political stability arising from there being a one-party government in existence in Turkey, and owing to almost all the centre-left parties, the Republican People's Party (RPP) most of all, having lost their power to pose as an opposition, the JDP has become the most powerful political party in present-day Turkey. The foreign political developments which have occurred in Syria and in Egypt, the majoritarian discourse following the Gezi Park protests/events and the increasing levels of authoritarianism following corruption allegations have had a notably attritional effect on the domestic and international public opinion of the JDP. However, these topics are not the subject of this article.

The JDP leader, Recep Tayyip Erdoğan, describes the party's political identity in the following way:

...JDP represents a new political style and a new understanding in Turkish political life. Our political fashion, political style [and] political culture present as conservative democracy; this is not only important for Turkey but it is also a very significant initiative in world politics. ${ }^{6}$

The image and expression of conservative democracy adopted by the JDP government, which makes Sunni conservatives content with the situation in terms of the votes cast in elections, is being questioned by the general public both inside and outside Turkey because of its policies favouring the status quo. This correlates with the continual problems faced by Alevis in spite of the concluding statements in the JDP programme that:

... Our Party sees and embraces all citizens of the Republic of Turkey as first class citizens, regardless of differences in religion, language, sect, regional origin, ethnic origin or sex. In our democratic understanding there is no obligation for differences to be converted to one another. ${ }^{7}$

A culture in which individual difference lives together side-by-side as part of historical tradition does not correspond to anything in contemporary reality. There have been a lot of assessments of this issue in the media, and Ülsever's analysis makes sense:

5 The result of these kinds of policies is that the Chief Prosecutor of the Supreme Court filed a case with the Constitutional Court against the JDP on 14 March 2008, claiming that the policies of the Party were not in line with secularism. With the announcement of the verdict on 30 July 2008, the Party received formal notice and half of its exchequer funding was cut.

6 As posted on the JDP's official website and taken from the Preface written by Recep Tayyip Erdoğan for Yalçın Akdoğan's book AK Parti ve Muhafazakar Demokrasi, İdeoloji ve Siyasal Kimlik.

7 JDP Party programme, Conclusion, available at: http://www.akparti.org.tr/english/akparti/partiprogramme\#bolum_. 
... What did the JDP, which claims to believe in freedom of conscience and belief, do for the rights of millions of Alevis? This is a kind of hypocrisy. They did not even take a single step for National Vision does not allow it! ${ }^{8}$

The political tradition that the JDP represents has an impact on Alevis' historical exclusion and their problems are related to this. This is a view that is generally accepted among Alevis. Such an understanding comes from events which have had important ramifications for the social position of Alevis - such as the Karbala incident; ${ }^{9}$ the Ottoman-Safavid War; ${ }^{10}$ and the Sivas Massacre ${ }^{11}$ - and there has been no attempt to change this.

Furthermore, neither is there evidence of change in the expressions and policy approaches of JDP leaders. What is more, there have been many experiences proving that, in the area of religion, an approach which favours the status quo and which is essentially statist has been persistently supported by the JDP. The JDP has made its expression of democracy questionable by following a political path which blocks the paths of communication with the leaderships of Alevi civil society organisations. Besides that, there has been no progress during the time of the JDP in particular problem areas concerning Alevism, to which we return in later sections. The Alevis have provided enough evidence; and, not only Alevis, but also non-Muslims and Sunni, have complained about it.

\section{Alevis during the period of the Republic}

Alevis, who make up nearly $15 \%$ of the Turkish population, are the second largest religious community in Turkey. Alevism is a different form of Islam; the major differences between Turkish Alevis, compared to Shi'a and Sunni Muslims, originate from their worship rituals. The Alevi approach to Islamic rules and religious practices is strongly criticised by Sunni Muslims. Due to the historical and geographical background, from central Asia to the Balkans, Alevism can be seen as a religious syncretism based on ancient Turkish beliefs and the other religious faiths encountered during the migration process. Despite some internal political, ethnic and religious-based divisions, Alevis see themselves as belonging to a distinct, united socio-religious community.

8 Cüneyt Ülsever (2008) 'Ergenekon davasına bakış açım’ Hürriyet 28 August.

9 In the incident of Karbala, which happened on 10 October 680, Hussein, son of Ali, the leading figure in Alevism, was killed by Yazid, the sovereign of Emevis. This incident is considered to be one of the most important steps in the separation of Sunni and Shi'a Muslims. Moreover, the death of Hussein has been part of Alevis' religious exercises over centuries.

10 The conflict between Ottomans and Safavids, both of whose founding figures were Turcoman, had important consequences not least for the people living in Anatolia at the time who suffered as a result of this conflict. Alevi-Sunni separation became prevalent as a result of this political dispute.

11 At a gathering, held with the participation of Aziz Nesin and arranged by an Alevi organisation on 2 July 1993, radical religious groups marched to protest. The result of these protests was that the hotel in which the gathering took place was set on fire. The security forces did not intervene and 37 people died in the fire. Subsequent to that, Alevis both in Turkey and in Europe have focused on organising themselves. 
Alevis suffered from pressure and discrimination, the reasons for which are referred to below, during the period of the Ottoman Empire. The most important evidence of this pressure and discrimination is the very effort to expel Alevi belief and culture from government-supported institutions, as well as the policies which are applied in education and religious services even up to the present day.

There are two important reasons for the pressures and marginality which Alevis, ${ }^{12}$ or klzılbaş (redheads) - the pejorative name in historical use - suffered during the Ottoman period. ${ }^{13}$ Firstly, Alevis perceive, interpret and implement Islam in a very different way from Sunnis. Secondly, they supported the Safavid Empire, another Shi'a-Turcoman state and an important eastern competitor to the Ottoman Empire under the leadership of Shah Ismail Hatayi. The result of their beliefs and this support has been that they have been exposed to a strict social and geographical marginality, which

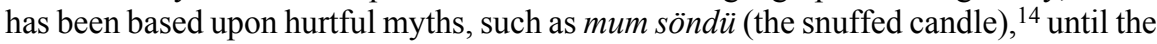
period of the Republic. Nevertheless, such dismissal of Alevis, especially in respect to their beliefs and culture, has carried on in the Republic period. Vergin states:

...just the same as in the Ottoman Empire, which did not recognised non-Sunni cults as legal existences in history, Alevi communities can still be neglected by the Kemalist state, too. ${ }^{15}$

Alevis, who are not and cannot be sufficiently represented on the stages of the bureaucracy and the political administration as a result of specific environmental characteristics and also their rural origin, still manage to exist with a population of about ten million without any solution to their problems. Moreover, the issue of Alevism has been used as a playground from time to time.

During the period of the Republic, it is generally observed that two main characteristics of Alevis have become prominent in particular. The first was to have beliefs and traditions which differ from religiously 'genuine' Islamic understanding, i.e. the Sunni approach. This approach is sometimes referred to as the 'kızllbaş' or 'rafizi'

12 For the evolution of the word Alevi see: Irene Melikoff (1998) 'Bektashi/Kızılbaş: Historical Bipartition and its Consequences' in T. Ollson, E. Özdalga and C. Raudvere (Eds.) Alevi Identity Cultural, Religious and Social Perspectives İstanbul: Swedish Research Institute in Istanbul: 5-6.

13 Vergin expresses this in the following way: '...This is because of the fact that they do not have an official way of getting organised, they had to face a cumulative force pushing them to marginality...' Nur Vergin (1991) 'Din ve muhalif olmak: Bir halk dini olarak Alevilik' Türkiye Günlüğ̈̈ 17, Winter: 16.

14 In the historical process, the Ottoman administration and firm Sunni peripheries have, on the grounds that the cem ceremony involves the participation of both men and women, qualified it as perverse and have named the cem as a 'snuffed candle ceremony'. For further, see: Robert Dankoff (1995) 'An Unpublished Account of Mum Söndürmek in the Seyahatname of Evliya Chelebi' in A. Popovic and G. Veinstein (Eds.) Bectachiyya Etudes sur l'ordre mystique des Bectachis et les groupes relevant de Hadji Bektach İstanbul: Editions Isis, pp. 69-73.

Vergin op. cit. p. 19. 
approach. ${ }^{16}$ The second one is being 'left-wing' in outlook, which is often termed 'communism'. ${ }^{17}$ It can quickly be suggested that such descriptions, or denominations, have gradually been weakening, especially during the $90 \mathrm{~s}$, although, beginning from this point, it is the belief characteristics that have become more prominent. For this reason, people whose 'left-wing' identities have previously been seen to be over and above their Alevi identity, or who have felt the necessity to hide their Alevi identity for many reasons, or those who have not been known to have an Alevi identity, can be known and accepted with this identity in public.

It cannot be suggested that Alevis have, from the foundation of the Republic of Turkey, ever been represented in politics in line with the proportion of their population thus far. There are various reasons for this, some of which are listed below:

1. the Alevi population has had predominantly rural characteristics from a historical and sociological point of view. This has caused them to fall behind in administrative, civil and military areas

2. especially since the Sunni approach became the official faith of the Ottoman Empire, beginning from the $16^{\text {th }}$ century, the Alevi population has been compelled to be a marginal and closed community due to their non-Sunni and unofficial beliefs 3. another reason is political marginality, which is also in conjunction with this religious reason. This situation has arisen because political marginality stems from the Ottoman-Safevid struggle and the support which Alevis gave to the Safavi state in this struggle.

These social, religious and political marginalities have led Alevi communities to persist as closed communities living in areas which are far from central ones and from the influence of the state. They are used to resolving all their religious, educational, legal, etc. problems by means of in-community mechanisms. ${ }^{18}$

After the collapse of the Ottoman Empire, Alevis supported the foundation of the Republic and had very good regard for Mustafa Kemal, who was the leader of the Republican movement. An important reason behind this support was the intention to establish close relations with Alevis, in order to gain the support in the struggle for independence of the two Alevi leaders who, at that time, represented the tekke of Hacı Bektaş. ${ }^{19}$ Alevis, who had been seen as 'aberrant' and 'baneful' elements in the

16 The word 'klzılbaş' although historically related to Ali and Shah İsmail by Alevis, is used to denote negative characteristics, such as "perverted', or 'faithless" by some Sunnis in comparison to 'rafizi' meaning 'reprobate'.

17 Subaşı puts forward '...Aleviler Türk politik yaşamında her zaman tartışmalı olmuş ve genellikle de birer 'suçlama' unsuru olarak kodlanmış üç ayrı kavramla (Kızılbaş, komünist, Kürt) ilişkilendirilmişlerdir...' ('Alevis in Turkish political life have always been controversial and there has often been an 'accusation' of association with the concept of the three separate elements codified as (klzllbaş, communist, Kurd)...'. Necdet Subaşı (2005) Alevi Modernleşmesi, Sırrı Fâş Eylemek Ankara: Kiyabiyat, p. 190.

18 Ali Yaman (2004) Alevilik'te Dedelik ve Ocaklar İstanbul: Karacaahmet Sultan Derneği Yayınları pp. 79ff.

19 Lit. 'religious complex at Hacı Bektaş'. Mazhar Müfit Kansu (1998) Erzurum'dan Ölümüne Kadar Atatürk'le Beraber II. Cilt Ankara: Türk Tarih Kurumu Basımevi, 3rd edition, pp. 92-494. 
Ottoman Empire for centuries, comprehended their acceptance by the founder, even if it was prior to the founding of the Republic and of the reformist movements which the Republic initiated. ${ }^{20}$ The traditional support given to the RPP by Alevis needs to be assessed in this context.

Following the foundation of the Republic, a state structure was developed based on citizenship, with secularity becoming one of the fundamental characteristics of the state, at least in its constitutional dimension, even if this was not always the case in practice. In line with this secularist understanding, which is unique to Turkey, the Diyanet, which is based in practice on a Hanafi-Sunni approach, was founded in order to take religion under the control of the state. An important implication of this has been that the number of Alevi people in the administrative civil/military elites has been very limited as a natural result of the rural and marginalised characteristic of the Alevi community.

The impacts of a Diyanet-centralised religious structuring were not felt at the beginning from the perspective of Alevis, who had began to migrate to cities, especially by the 60 s. However, the Diyanet became institutionalised in time and had substantial resources, bigger even than many ministries of state, in terms of personnel and budget. In this process, the 'forgotten' position of Alevi people became more apparent.

In parallel with the right-left polarisation experienced in the country, both religious and cultural erosion amongst the Alevi people have continued to persist since the 1980 coup d'état. ${ }^{21}$ Moreover, the new religious education structure, including obligatory RCE courses anticipated by the 1982 Constitution and the new Diyanet structure, further confirmed this Hanafi-Sunni approach. By this time, and in parallel with migration from rural areas to the cities, and the consequent developments, Alevi people have become alienated from their beliefs and traditions. In this process, the obvious role of religious education ${ }^{22}$ given in İmam-Hatip high schools and divinity faculties, and in religious services, cannot be denied.

Throughout the political history of the Republic, the process can be summarised in respect of the political preferences of Alevis, as a belief group rather than as an ethnic

20 Alevis' allegiance to Atatürk and the reforms of the Republic are generally accepted by most researchers. For example, see: Karin Vorhoff (1998) “'Let's reclaim our history and culture!”Imagining Alevi Community in contemporary Turkey' Die Welt des Islams 38: 230; Tahire Erman (1998) 'Becoming "urban" or remaining "rural": the views of Turkish rural-to-urban migrants on the "integration" question' International Journal of Middle East Studies 30: 548; Hugh Pope and Nicole Pope (2004) Turkey Unveiled A History of Modern Turkey Woodstock, New York: Overlook Press, p. 134.

21 Some bureaucrats of the regime in place after the 1980 military coup saw it as a 'public duty' to build mosques in Alevi villages. For examples, see: (Anonymous) (1996) '38'den Bugüne' Dersim 2/2, January, pp. 19-23; Tanıl Bora, Tanıl, Hatice Aydoğdu, Şazimet Değerli (1987) 'Alevîliğe Ne Oluyor?' Yeni Gündem 4/77, 23-29 August: p. 14.

22 Even the executives of the Diyanet have mentioned how Alevism is disregarded: see: Abdülkadir Sezgin (2005) 'Balkanlar ve Doğu Avrupa'yı Müslümanlaştıran Hacı Bektaş Erenleri' Türk Yurdu 25(210), February, p. 64. 
sect, as follows. The party supported was the RPP in the period of the single-party state, ${ }^{23}$ and the Democratic Party (DP) in the period of the transition to a multi-party system. However, the result of the solidarity between the Democratic Party and religious groups, defined by Mardin as an 'alliance of Sunni groups', ${ }^{24}$ Alevi people have again tended towards the RPP.

The Union Party (UP), which addressed the Alevi with its emblem, programme, administrative staff and voters, took its place in Turkish political life for a period after 1966. The general presidency of this Party was implemented by Huseyin Balan between 1966 and 1969 and Mustafa Timisi ${ }^{25}$ between 1969 and 1980. The Party's managers were, in the main, from the Hacı Bektaş Celebi family, who were esteemed especially by Alevi people in central Anatolia, including Ali Naki Ulusoy, Kazim Ulusoy and Yusuf Ulusoy. The UP received $2.8 \%$ of the votes and gained eight seats in the Grand National Assembly in the 1969 elections, but was not able to organise all Alevi votes under its roof. The UP later declined and left Turkish political life. ${ }^{26}$

Following the military coup in 1980, the votes of Alevi people became concentrated in left-wing/social democratic parties, such as the Popular Party (PP); the Social Democracy Party (SODEP); the Social Democratic Popular Party (SDPP); the RPP; and the DLP (Democratic Left Party). We cannot say that the votes of Alevis have gone, en bloc, to certain political parties. ${ }^{27}$ However, it is a reality that there is a traditional

23 Throughout the history of the Republic, it is known that Alevis have generally been supporters of left-wing parties and movements. Because of this, Alevis who support parties other than left-wing ones are not often mentioned. Behind Alevis' support for RPP and other left-wing parties is that, unlike the Sunni-focused structure of the Ottoman Empire, the new Republic was built upon a secular basis and thus the parties supported have been 'more distant' to religion compared to right-wing ones. This positive image of the RPP's religious expressions, which are actually no less than right-wing parties, is one of the main reasons why Alevis have supported the RPP until the present day.

24 Şerif Mardin (1992) 'Türkiye'de Din ve Siyaset' Makaleler 3, 2.b. İstanbul: İletişim Yayınları, p. 125.

25 Mustafa Timisi was a member of the administrative board of Turkiye İş Bank, coming from the RPP's quota.

26 In 1970, five deputies, including three members of the Ulusoy family, were dismissed from the party as a result of proposing a vote of confidence in the party led by Suleyman Demirel. The Turkish Unity Party lost its support, gaining only $1.1 \%$ of the votes in the 1973 elections and only one seat in the parliament. Also see: Elise Massicard (2007) Türkiye'den Avrupa'ya Alevi Hareketinin Siyasallaşması Çev. A. Berktay, İstanbul: İletişim Yayınları, p. 57.

27 Massicard also expresses this as: '...specially starting from 1990s there has been a diversification in the vote. Alevis did not tend to vote only for one single party in an unchanging fashion....' ibid. p. 195. 
sympathy among Alevi voters for these social democratic parties. ${ }^{28}$ It can also be seen that the existence of Alevi candidates has also been an important factor in these preferences. ${ }^{29}$ Furthermore, in addition to the identity of the candidates, their regional characteristics can also be important as regards the parties for which votes are cast. ${ }^{30}$ For example, right-wing parties may sometimes be supported by Alevi people in western and central regions; whilst the Democratic Society Party (DSP) collects the vast majority of votes in regions such as Tunceli, Varto, etc.

In 1987, the Welfare Party (WP), which was founded as an extension of National Vision, directed itself to the public other than its traditional voters in order to become more influential in the political area and became successful in the 1991 and 1995 elections in terms of increasing its share of the vote. It is obvious that this encompassed Alevis, but the Sivas Massacre in 1993 again made such a convergence impossible. ${ }^{31}$

The achievements of the WP and the VP in municipal elections and then in general elections have developed further with the JDP. The WP has held power in various municipalities, especially in Istanbul's 1994 municipal elections. After the general elections of 1996, it became a major partner in politics and Necmettin Erbakan, the general president, even sat as Prime Minister in coalition with the TPP.

The officials of the WP, especially Erbakan, have delivered positive messages to Alevi people. Within this context, we might cite the (rather limited) Alevi accessions into the WP and the press declarations of Erbakan on the Sunni-Alevi brotherhood; ${ }^{32}$ the close relations with the Ehl-i Beyt Foundation, which is accepted as being close to

28 The Democratic Peace Movement is another political movement seen as an Alevi party by the general public in relation to its founding cadre and supporters. DPM, which was established on 2 October 1996, was closed by the Constitutional Court on 28 December 1998 [Constitutional Court, «E.S.: 1997/5; K.S.: 1998/5; K.G.: 28 December 1998» Resmi Gazete 23631, 6 March 1999, s. 7)]. After that, the leader Mehmet Eti and the executive committee resigned from their duties and established the Peace Party. In May 1999, the general president of the Peace Party, Ali Haydar Veziroğlu, announced that the general assembly delegation had decided to close the party. ('Demokraside örnek çekilme' Milliyet 11 May 1999. p. 15).

29 Schüler draws attention to this issue, saying: '...In some election districts the RPP's choices of candidates are considered to be the most effective factor influencing the election results. When Alevi candidates are missed out, as in the case in Tokat, a serious amount of loss in the level of Alevi votes happens to be the case...' Harald Schuler (1999) Türkiye'de Sosyal Demokrasi Particilik, Hemşehrilik, Alevilik İstanbul: İletişim Yayınları, p. 184.

30 Massicard, op. cit. p. 151.

31 'Erbakan: Alevi-Sünni kardeştir' Zaman 1 June 1995. Furthermore, M. Hakan Yavuz states that Bahri Zengin, from the liberal wing of the WP, led relations with Alevi communities and worked on an important project related to Alevis. M. Hakan Yavuz (1997) 'Political Islam and the Welfare (Refah) Party in Turkey' Comparative Politics 30(1), October, p. 75.

'FP Alevi Kurultayı'nda' Hürriyet 14 March 1999. 
the WP and its successor, the VP; ${ }^{33}$ and having candidates nominated in close relationship with this Foundation in the VP lists in 1999.

Again, beginning from this period, it can be seen that various studies have been made in low-income districts where Alevi people live, such as Nurtepe, Kagithane, etc. predominantly in order to attract the votes of Alevi people. For example, the specialist consultants assigned on this issue have submitted reports on Alevis to the Party and the municipal administration; employees of municipalities whose number was few, but which include those of dede $e^{34}$ origin, have been used in election campaigns; food and other aid has been made in Alevi neighbourhoods with low incomes; various activities have been organised in co-operation with the Ehl-i Beyt Foundation, which is one of the few associating with the WP and VP and supporting Alevi organisations; Alevi candidates have been added to the lists in Tunceli and Mersin; and a limited number of politicians of Alevi origin have taken their place among the founders and parliamentarians of the JDP. ${ }^{35}$

Another point which must be mentioned is that there is an interesting alliance between the secular sections of the state and the tradition, from National Vision to the JDP, on the formation of a religious space in line with the Hanafi-Sunni understanding of Islam. As a matter of fact, both these parties tend not to intervene in the Hanafi Sunnioriented structure of religious services and religious education. This situation has become more apparent in the period of the JDP government. However, this apparent compliance includes very different and varying approaches when the details are examined.

The most important of these differences is that the secular state elite tends to see Alevis as a protective element in the secular system, even as the 'guarantee of secularity'. However, the National Vision/JDP tradition is not satisfied with this situation, in terms not least of the challenging and negative attitudes of Alevis on the turban/ headscarf issue, which is about as sensitive an issue to such a tradition as the existence in the first place of an alliance between Alevis and secular groups. It is known that these secularists have been upset by the criticisms of the National Vision/JDP tradition on the fundamental principles of the state, but especially the secular principle, before and during its time in power.

Moreover, it may be seen that many political parties from this tradition have been banned as a result of their tendency to question the fundamental principles of the state. In addition, unlike the state's secular elites, the JDP arose out of that tradition and obviously has a very different attitude on issues such as Koran courses, İmam-Hatip high schools, the Curriculum of Religious Education, etc.

33 After the 12 June 2011 general election, the JDP gained $49.83 \%$ of the vote and 326 seats in the parliament. According to the information I have gathered, two deputies were of Alevi origin. It has been expressed that, in the previous term, there were four Alevi-origin deputies in the Party.

34 Alevi spiritual leader.

35 In one newspaper, Alevis' views on the JDP are summarised as follows: '...As for Alevis, for many the JDP is the representative of National Outlook; being the community with the most to fear from a Sunni regime, they are the ones who are the most likely not to believe that JDP is a different party...' 'Önyargıları kırmak zor' Sabah 6 June 2007. 
However, despite all these differences in detail, it is clear that the JDP and certain civil/military sections are in consensus on the arrangement of the religious sphere in Turkey, in line with Sunni Islam understanding. Therefore, it would not be incorrect to say that, between 2002 and 2008, the state in Turkey was in harmony with the National Vision tradition and the JDP on the continuity of the status quo in fields such as the arrangement of religious education and the spaces and institutions in which the state may intervene.

\section{Mutual misunderstandings}

Alevis believe that the state, in co-operation with devotional sections of Sunnis, treats the Alevis like a 'foster child', and they choose to express this victimhood status on all occasions. In addition, it is clear that there is deep distrust as well as a lack of lines of communication between Alevis and these sections. In fact, this is the result of accumulated feeling created by the historical process, with the distrust that this has engendered leading both parties to act with suspicion towards the behaviour of each other.

There are many factors shaping the image of the JDP in the view of Alevis. However, here the most important issue is that, nowadays, the vast majority of Alevi people believe the JDP to be the representative of 'Sunni Islam' and the successor to the National Vision movement. Indeed, these two approaches are related: an important feature of the National Vision movement is that it is based on the Sunni sect. The JDP is thus thought to be, in exactly the same way as National Vision, a movement which is contrary to the fundamental principles of the Republic and which it sees as 'bigoted'. Declarations and actions against secularism and against Ataturk, and symbols such as the headscarf/turban, and religious clothing, are accepted as the main indicators of this situation.

In addition, Alevis denounce Sunni Islam for the massacres to which they have been exposed since the Karbala incident. Alevis lived through the same discrimination in the period of the Ottoman Empire and during events such as the Maraş Massacre and the Çorum Pogrom, ${ }^{36}$ as well as the events at Sivas. They believe that Alevis represent victimhood and peacefulness whilst Sunni Islam represents the cruel party in power. Such events as these are all seen in association with the JDP, which is seen as an extension of Sunni Islam.

It is not possible to evaluate these events exactly in the same way in terms of their periods and reasons; it is the historical and sociological process experienced by the Alevis which has resulted in such a perception. Furthermore, the pejorative terms used by Sunni people are met in response by Alevis who refer to Sunnis as 'Yezit'. ${ }^{37}$

36 The Maraş Massacre of 1978 and the Çorum Pogrom of 1980 both originated in an ideological right-left polarisation, but it was mostly Alevis, associated with left-wing ideology, who were hurt; plenty of Alevi families lost their lives and plenty families had to emigrate from Maraş and Çorum to the cities.

37 Yezit is the one who killed the grandson of the Prophet, and this term is regarded as a very humiliating response; the name Yezid has never been used amongst Sunnis in Turkey. 
A view of the JDP as the representative of 'Sunni Islam' bears many negative characteristics for Alevis. The JDP being in power is a situation which makes Alevis recall the experiences of the Ottoman Empire and raises the perception of negative discrimination. Despite the JDP being in power in central government and in the vast majority of municipalities, it appears to Alevis to be unwilling to endeavour to resolve their problems, such as anti-democratic actions and ones which are contrary to freedom of belief, taken in co-operation with conservative sections of the state bureaucracy. Furthermore, the demands of Sunnis are given priority and they are favoured in the levels of the state administration. This discrimination against Alevi people was also expressed in the letter written by JDP parliamentarian, Reha Camuroglu, after resigning from the position of consultant to the Prime Minister. ${ }^{38}$

One or two JDP deputies of Alevi origin, and the existence of Alevi-origin administrators in municipal administrations whose number could, nevertheless, be counted on the fingers of one hand, are probably not sufficient to change this perception.

In order to understand the view of the JDP regarding Alevis, it is necessary firstly to consider that there is a section of society which believes religion to be under pressure, with religious people being exposed to 'discrimination' in the Republic of Turkey.

It is also clearly understood, from declarations made from time to time, that the thoughts of JDP members are consistent with those made by devout Sunni Islamists. Until recently, Alevis were not only been called pejorative names and thought of as a non-Islamic, heretic group, but many aspersions, such as not bathing, immorality, irreligiousness and having orgiastic ceremonies, were still cast in their direction. Such myths can still be spread even today, not only in Turkey but also in Europe: for example, such findings can clearly be found in the field study which Mandel has carried out into people of Turkish origin living in Berlin. ${ }^{39}$ However, it is obvious that such claims cannot be said to exist with support from the official discourse of the state, unlike in the period of Ottoman Empire. Now, such an approach can be pursued only in limited contexts, and is confined to in-house and in-communion environments in those metropolitan areas where Alevi and Sunni communities blend together. Furthermore, even some Sunni community leaders have declared the sensitive mum söndü issue to be a complete fabrication. . $^{40}$

At the religious base of this bias towards Alevis, there are the different approaches to Islamic history and institutions and the rules of Sunni Islam. For example, Alevis do not comply with certain worship and religious rules, such as the five pillars of Islam and the thirty-two obligations which Sunnis accept as the essentials of being Muslim. Instead, they adopt the weekly cem as the basic form of worship. They fast for twelve

38 Şükrü Küçükşahin (2008) 'Erdoğan'1 şoke eden istifa' Hürriyet 12 June 2008; 'Çamuroğlu: İstifa ettim ama hâlâ trendeyim' http://www.ntvmsnbc.com/news/449772.asp.

39 Ruth Mandel (1995) 'The Alevi-Bektashi identity in a foreign context: the example of Berlin' in A. Popovic and G. Veinstein op. cit. pp. 429-430. In the same way, similar opinions were expressed to me in my research in Duisburg in Germany: Ali Yaman (2007) Alevilik ve Klzılbaşlık Tarihi İstanbul: Nokta Kitap, p. 140.

40 'Gülen'in açıklaması, Alevî camiada memnuniyetle karşılandı' Zaman 25 January 2008. 
days in the month of Muharrem instead of Ramadan. Additionally, there are substantial, and important, doctrinal differences between both sects. ${ }^{41}$

Nowadays, in the debate on Alevism among Sunni intellectuals, the common approach is that Alevism is a branch of Islam. Indeed, Sunni dignitaries, seeing that Alevism has become alienated from them, have backed down from excluding and accusing Alevis of deviance, directing themselves instead towards a discourse that they are Muslims by highlighting the idea of union.

Today, there is also an inconsistency between the perception of Alevis by JDP managers and the real situation facing Alevis. This creates tensions from time to time. The most important role at the heart of this inconsistency is the discrepancy between the exclusionist approach previously applied to Alevis and today's perception of Alevism, under which there is no difference between Alevi and Sunni. However, those who don't want to acknowledge the problems of the Alevi include not only such people but also secularists from Sunni environments who have been educated in this direction. Şerif Mardin states:

...Soldiers and secular intellectuals believe that the sectarian competition between Sunnis and Alevis is a problem which has been created artificially. However, the roots of these sectarian differences in Turkey are really very deep... ${ }^{42}$

Subsequent to the foundation of the Turkish Republic, the political powers have ignored this reality and identified that the belief- and cultural-based differences between Alevis and Sunnis are artificial.

In conclusion, all these policies and attitudes have not led these two sects to come to know each other and show understanding for their differences. On the contrary, the problems have further deepened and been carried to international platforms from the national one.

41 Alevis claim that the three caliphs after the Prophet, namely Abu Bakr, Umar and Uthman, seized the rights of Ali, the son-in-law and nephew of the Prophet. They reject A'isha, one of the wives of the Prophet, because she declared war on Ali (the Battle of the Camel, in 656), and they also reject Muawiyah and his son Yazid, from the Umayyad caliphate, although Muawiyah is accepted as a Revelation Scribe and a successful leader by Sunnis. Interestingly, an important portion of Sunni theologians do try to defend Muawiyah, but have never advocated the actions of Yazid. 
The factor which determines JDP-Alevi relations is largely the demands of Alevis and the responses given/not given to them. The demands of Alevis in Turkey can be summarised as follows, in general: ${ }^{43}$

1. obligatory RCE courses should be either optional or re-arranged with the content meeting the demands of Alevis. The teachers giving these courses should be prevented from inculcating a Sunni understanding in Imam-Hatip high schools and/ or divinity schools. Courses should contain all religions, not only Islam, and they should be given objectively and in the context of a supra-religious and supra-sectarian understanding

2. cemevi should be accepted as places of worship and have the opportunity to benefit from the facilities which places of worship currently have. Opening courses for officials in cemevi, building schools and meeting the salaries and utilities costs of these institutions are included in these demands

3. the Diyanet cannot have a supra-sectarian structure, but does adopt a biased approach from time-to-time in religious issues in practice, so it should either be completely disposed of or re-structured to provide a representation for Alevis.

In addition to these important problems, there are other demands, such as discrimination being stopped; justice as regards those responsible for the Sivas Massacre and the Gazi Quarter riots; no compulsory building of mosques in Alevi villages; including Alevism on the TV and radio broadcasts of TRT, the official broadcasting institution of the state; and the establishment of departments on Alevism in universities. ${ }^{44}$

Considering the process from the 2002 elections up to the present day in general, it is difficult to say that JDP-Alevis relations are moving in a positive direction. It may be seen that the JDP government has fallen behind its predecessor governments in respect to relations with Alevis.

43 And not only Alevis living in Turkey: those living abroad have similar demands. At Erdoğan's visit to Köln with Reha Çamuroğlu, İstanbul Deputy, the European Co-ordinator of the Cem Foundation, Alişan Hızlı, mentioned the problems of Alevis living in Europe and that they had three demands. Hizlı said: 'We want cemevi in Europe, open cemevi here, too. We want our children to be raised in better conditions. That is why we want to have educators who would explain Alevi beliefs to Europe. Dedes alongside cadres should also be sent to Europe. There are approximately 850 thousand Alevis in Europe. None of the Turkish governments have helped them...' 'Alevilerden 3 istek' Milliyet 23 February 2008 http://www.milliyet.com.tr/2008/02/23/siyaset/axsiy03.html.

44 In the Alevi Declaration signed by Alevi, Sunni and other intellectuals and announced in 1990, in summary there were statements such as: Sunnis are invited to abolish their prejudice against Alevis and to abdicate their negative claims; and intellectuals should defend the rights of Alevis in the framework of defending human rights. The media should also include Alevis in their agenda. According to their demands, the state's official radio and television should also include Alevis in their programmes. Alevis should also be included in the Diyanet. The Diyanet should not receive a share from the budget but, if it does, Alevis should also receive financial support in accordance with the size of the Alevi population. The trend of building mosques and appointing imams to Alevi villages should be stopped. Alevism should also be included in obligatory RCE courses and Alevi students should not be forced to take those Sunni-centred courses. Cumhuriyet 15 May 1990. 
In the pre-JDP period, some positive steps had been taken in relations with Alevis. Presidents and Prime Ministers had attended cemevi opening ceremonies, dialogue had been established with Alevi associations and foundations, even if it was little, and monetary support was provided for Alevi associations/foundations and cemevi in nonordinary ways.

In contrast, JDP leader and Prime Minister Recep Tayyip Erdoğan has not replied in the affirmative to the demands regarding the belief and cultural problems, as well as the demands for meetings of publicly-known Alevi non-governmental organisations. The JDP has been criticised even by columnists in media organs which are close to the Party on the grounds that the JDP has remained insensitive to the problems of Alevis and has not even given meeting dates to Alevi associations/foundations. In this regard, Hüseyin Gülerce, from Zaman daily newspaper, wrote following an interview with İzzettin Doğan, General President of the Cem Foundation, that:

... I agree with the criticisms which Mr. Doğan expressed because of the insensitive attitude of the JDP government. This government has been founded with the claim that it would adopt religious and moral freedom above everyone. Believe me, it was heart-wrenching when I asked Mr. Doğan on Sunday Talk, 'Did you negotiate with Mr. Prime Minister or another government official on these subjects?' and he replied 'No, because I could not even get a meeting. ${ }^{45}$

It is remarkable that columnists such as Fehmi Koru from Yeni Şafak, which generally supports the policies of the government, criticises the day-by-day shift of the JDP to the status quo/statist line in religious issues. ${ }^{46}$

At least, the JDP government is statist on issues regarding Alevism - but it is revisionist when the issue is the headscarf/turban, courses on the Koran and İmam-Hatip high schools.

\section{Conclusion}

In the century-long history of the Turkish Republic, the problematic structure of religious affairs, which is shaped both by the legacy of the Ottoman Empire and by the concerns of the establishers of the Republic, keeps on growing ever-more complex. The relationship between state and religion, which is considered and determined to be an area for engineering, tends to implement its own programme without considering the religious atlas of Turkey. This approach, which is predicated on the majority and also on control and intervention in the religious realm, is comprehensible considering that the Republic was born from the ashes of the Ottoman Empire and the time of its establishment. Nevertheless, it has turned into a much more problematic issue for Turkey in later years. Alevism constitutes one part of this problem area. Turkish gov-

46 Cited by Ahmet T. Kuru (2006) 'Reinterpretation of Secularism in Turkey: The Case of the Justice and Development Party' in M. Hakan Yavuz (Ed.) The Emergence of A New Turkey, Democracy and the AK Party Salt Lake City: University of Utah Press, p. 144. Kuru also states, in the same article: 'At the present time, due to its own statist view and the resistance of the Kemalist establishment, the JDP has not succeeded in reforming Turkish secularism.' p. 153. 
ernments have had different political views, but they have adopted Sunni Islam in principle, while carrying on with religious education and services which have led to the exclusion of Alevis. This exclusion shows itself in three important fields, such as obligatory RCE courses, cemevi and the Diyanet.

The JDP, which grounds its political existence greatly on the demand for freedom in the religious area, has contradicted both its party programme and its political basis given its policy implementation measures since 2002. Perhaps, this contradictory approach to Alevism is related to the views of JDP leaders, as well as the party base and political cadres. Such a point of view is about defining and transforming Alevism in the context of Sunni Islam instead of trying to understand it. Besides, this biased approach continues to surpass the JDP's party programme and its different national/international statements and promises. In spite of all the national and international suggestions and pressure, there is simply no change other than the superficial, and limited changes in the curriculum of obligatory RCE courses, while the JDP's efforts in forming Alevi organisations which support the Party leaves no place for optimistic expectations on this issue. The great level of agreement between the policies of the JDP government and the conservative parts of the state bureaucracy draws our attention. In other words, it is the approaches of the bureaucrats of the Diyanet and the Ministry of Education which are shaping JDP policies on Alevism.

The developments since 2002 have seen Alevis continue to feel discontented with the JDP and its political tradition. That the tradition of National Vision, associated by Alevis with the 1993 Sivas Massacre, could tend towards a renewal of the events of the past with the JDP, although this is another version of National Vision. Besides, this kind of renewal would have contributed much to the JDP claims of being different than National Vision. Given these developments, it is impossible to speak of the existence of such an intention, however. Even in the times when the RPP was not in popular focus, Alevis' lack of confidence in JDP takes its source from the policies of the JDP, which is to ignore Alevi problems. These conditions still continue in the JDP's second term. In time, Alevis have become more organised, the cemevi have become more institutionalised and the EU process will make JDP policies harder to implement.

The result is that it would be appropriate to state that the JDP-Alevi relationship is dominated by distrust. Ultimately, the JDP remains insensitive to the problems of Alevism and, in so doing, is acting against its expression of democracy and endangering the persuasiveness of other democratisation efforts. 